\title{
Effect of Financial Liberalization on Savings and Investment in Nigeria
}

\author{
Danjuma Ahmad ${ }^{1}$ and S.P.Premaratna ${ }^{2}$ \\ ${ }^{1} \mathrm{PhD}$ Student, Department of Economics, University of Colombo \\ ${ }^{2}$ Department of Economics, University of Colombo
}

\begin{abstract}
In Nigeria, measures were taking by government between the period 1986 to 2005 to liberalise the financial sector as part of the overall structural adjustment programme (SAP) with the aim to promote economic growth and alleviate poverty. The financial reform assumes that deregulating the financial market will eliminate the distortion and fragmentation of the financial market. It will also improve the mobilisation of savings as well as efficiency in allocation of funds to viable investment projects in the economy. This in turn will help in accelerating economic growth. Literature in the area posits that liberalising interest rate and deepening of the financial market is growth enhancing. This hypothesis is tested by identifying two basics channel through which financial liberalisation is operational - - savings and investment, and allocative efficiency. The analysis was carried out using macro data from Nigeria by employing Two-Stage-Least Square (2SLS) instrumental variable technique to analyse the data. Major findings pointed out that interest rate as determinant of savings is not statistically significant, and rising interest rate negatively affect investment growth. Secondly, investment follows the standard accelerator theory. Furthermore, growth in the stock of money is positively related with investment but statistically insignificant. Lastly, there is a considerable deepening in the banking sector, however, the capital market does not
\end{abstract}


positively impact on the allocation of credit in the economy. Perhaps investment in the market is more of speculation that crowd out investment in the real sector thereby retrogressing the economic growth. The study recommends that government intervention is necessary for rapid and sustainable economic growth in the country especially policies like income policies and interest rate regulations as well as policies that smoothen consumption in the economy. Also, policy makers should focus on stabilising the economy to reduce the macroeconomic uncertainties especially exchange rate and inflation volatility, that impede the growth of private investment.

Keywords; financial liberalisation, credit allocation, financial repression, savings, investment, economic growth Nigeria

\section{Introduction}

Up to the middle of the 1980s, Nigeria's economic policy was more of direct control. Interest rate, exchange rate and credit allocation to different sectors in the economy were not on the basis of market determination, but based on government directives (Ayogu, Emenuga, $\&$ Soludo, 1998). The prevailing situation was challenged based on the following reasons: passive competition; poor customer service; significant government ownership in the banking sector; sectoral credit allocation; limited expansion of domestic credit to private enterprises; interest rate regulation; restriction to flows of foreign direct and portfolio investments due to capital account control; and fiat monetary policy (Ayogu et al., 1998).

As from 1986, the economy gradually started moving away from direct control to a more liberal or deregulated economy. As a result of that, 
several financial reforms were introduced, even though it encountered several policy reversals over the time as well. Broadly speaking, these reforms were referred to as financial liberalisation reform. The main objectives of the financial market reform in Nigeria as pointed out by the Central Bank of Nigeria in its monetary policy report include the followings: Removal of controls on interest rate to increase the level of savings and improve efficient allocation of credit in the economy; elimination of non-price rationing of credit to reduce misdirected credit and increase competition; adoption of indirect monetary management in place of the imposition of credit ceiling on individual banks; enhancing of institutional structure and supervision; strengthening the money and capital market through policy change and distress resolution measures; and improving the linkages between formal and informal financial sectors (CBN, 2007).

Thus, the philosophy behind the financial liberalisation is in twofold: first, quantity effect through generating higher savings and investment in the economy, and second, quality effect by efficiently allocating capital to profitable investment. If these set of objectives were achieved, it is expected that the economic growth will be enhanced. The downward trend in the key macroeconomic indicators will be reversed especially unemployment, poverty and inflation. Although, financial repression discourages savings, but Nwaobi (2003) argued that in the case of Nigeria it is not as serious as the financial liberalisation proponents hypothesised. However, Akande and Oluyomi (2010) when examining the relevance and application of the theoretical prescription of the Two-Gap model in Nigeria noted that inadequate savings and foreign exchange are responsible for low investment and growth of the 
economy. Similarly, statistics from World Bank Development indicators in 2016 with respect to domestic credit to private sectors shows that Nigeria's domestic credit to private sector as a percent of GDP was 15.68 percent, and as such ranked at $146^{\text {th }}$ position in the world. This posed a question as to whether the dwindling growth of the Nigeria's economy was due to savings or credit deficiency.

Despite the strategic reforms, Nigeria's growth performance has been dwindling for the past three decades, making it difficult to address the macroeconomic issues facing the country. This called for the study to assess the policy and examine it to see whether the poor performance was as a result the policy or other economic issues are behind the stagnation. The question now is why did the performance of the economy has been dwindling for the past three decades with regards to savings and investment growth? Or, in other words, why is there no steady growth in savings and investment in the economy? Can this poor performance be associated with the financial liberalisation reform? Is there evidence that the reform has led to efficient allocation of capital in the economy? Previous studies focused on the quantity effect of the reform, but less attention has been given to the issue of allocative efficiency. Thus, the objective of the study is to find out whether financial liberalisation has improved on the growth of savings and investment in Nigeria, and or test whether the reform has also improved the efficient allocation of credit in the economy.

The paper is structured as follows; section II reviewed the performance of the economy before and after the reform. While, section III reviewed the related literature pertaining to the impact of financial liberalisation on savings and investment. Section IV developed the econometrics 
methodology used in analysing the impact. Three models were developed and Two-Stage Least Square instrumental variable regression technique was employed in analysing the data due to presence of endogeneity in the models. Section V present and discussed the results of the findings. Section VI concludes and offered recommendations.

The study is of significant as it shed more light on the controversies surrounding the effect of financial liberalisation on savings and investment growth which has long been debated within the academic circle. In the Nigerian context, the study pointed out that interest rate does not significantly and positively contributes to savings and investment growth in Nigeria. The study is also of significant as it shows how the Nigerian economy is credit constrained contrary to the assertion that the economy was savings constraint. Another significant contribution of the study is the way it observed investment in the capital market crowd out real sector investment and call for government active policy rather than passive policies to drive the economy further.

\section{An Overview of the Nigerian Economy}

Table 1 summarises the performance of the economy before and after the liberalisation period looking at some key macroeconomic variables. 


\section{1: Real Sector Performances}

\begin{tabular}{|c|c|c|c|c|}
\hline Item & $\begin{array}{c}1981- \\
1989\end{array}$ & $\begin{array}{l}1990- \\
1999\end{array}$ & $2000-2009$ & $\begin{array}{c}2010- \\
2017\end{array}$ \\
\hline A. GDP GROWTH RATE (\%) & -2.04 & 2.62 & 8.90 & 3.82 \\
\hline a. Agricultural GDP growth rate (\%) & 23.51 & 34.02 & 25.96 & 9.48 \\
\hline b. Manufacturing GDP growth rate (\%) & 18.37 & 15.72 & 8.94 & 8.43 \\
\hline c. Services GDP growth rate $(\%)$ & 2.69 & 3.75 & 11.01 & 4.03 \\
\hline $\begin{array}{l}\text { B. Gross Fixed Capital Formation (\% of } \\
\text { GDP) }\end{array}$ & 18.74 & 10.37 & 8.23 & 15.00 \\
\hline C. Gross Investment (\% of GDP) & 17.71 & 10.42 & 8.24 & 15.71 \\
\hline D. Gross National Savings (\% Of GNI) & 20.89 & 14.58 & 19.47 & 25.06 \\
\hline $\begin{array}{l}\text { E. Credit to Private Sector (as \% of } \\
\text { GDP) }\end{array}$ & 15.42 & 11.51 & 19.27 & 13.86 \\
\hline
\end{tabular}

Source: Author's computation from CBN and World Bank Development Indicators, 2018

The average growth of GDP in the 1980s was -2.04 percent. This slightly improved to 2.62 percent in the first decade after the reform. Although, the economy has undergone structural transformation towards the late 1980s, but it can also be argued here that the changes in the GDP growth between the 1980s to 1990s was not as a result of improvement in the sectoral performances rather it was as a result of improvement in the oil price (Ibrahim, 2018). Findings by Ibrahim (2018) shows that oil price exerted positive influence on aggregate national output, however, with respect to manufacturing and agricultural sector the influence is negative. In the early 1980s world oil price 
crashed sharply, this hit the economy negatively. The study further argued that fluctuations in oil price induces uncertainty in the real sector and also weakens the effectiveness of government fiscal management. Although, the economy continued to grow at an average growth rate of 8.9 percent in the second decade after the reform until 2010, but it is difficult to ascertain whether the growth was as a result of the financial reforms or due to stabilisation of the oil price. This evident by the end of the third decade, where the growth slows down to 3.82 percent and ended with a recession in 2016.

Looking at the sectoral contribution from fig 1 it shows that both agriculture and manufacturing does not contribute reasonably to the economic growth. Prior to the liberalisation, agriculture and manufacturing are the main employer of labour and contribute substantially to the growth of GDP. The average contribution of the agricultural sector during the decade prior to the reform was 23.51 percent. This dropped to 9.48 by the end of the last decade of 2010 . Similarly, the average growth of manufacturing GDP in 1980s was 18.37 percent. However, this continually decreasing to as low as 8.43 percent in 2010 to 2017 period. Employment in the sector also declined persistently for example, as at 1980s, the number of labour force in the textile industry stood at 700,000. However, by the end of 1995, this fell to 40,000 (Newman et al., 2016).

In 1980s, the proportion of service sector in the GDP was 2.69 percent, this significantly rise to 3.75 and 11.01 percent in the first and second decades after the reform respectively. The statistics above shows that Nigeria's service sector, even though performed poorly, but gained steady growth as compared to agricultural and manufacturing sectors, 
until 2010 when it starts declining. The ratio of credit to private sector as a percent of GDP fell to 13.86 percent from 15.42 percent between 1980 to 2017. In the period between 2000 and 2009, the proportion of credit to private sector increased to 19.27 percent. While at the same period, the growth rate of manufacturing and agriculture fell to 8.94 percent and 25.96 percent respectively.

Investment is considered to be essential for sustaining higher economic growth. Indicator of gross fixed capital formation shows that investment suffers throughout the periods. Total investment and fixed investment averaged 18.74 and 17.71 percent of the GDP in the 1980s respectively, have both declined to 15 percent in the last decade recording worst performance of 8.23 and 8.24 percent respectively in the second decade. Declining investment has contributed to the poor performance of the real sector especially the manufacturing and agricultural industries. National savings has improved considerably from 20.89 percent in 1980s to 25.06 percent between 2010 to 2017 on average. One important thing to note here is that as the savings increased, investment reduces. Only in 1990s that both the variables decreased simultaneously. Investment dropped to 10.42 percent from 17.71 percent in 1980s, while savings dropped to 14.58 percent from 20.89 percent in the same period.

In fact, the performance of the real sector based on the statistics discussed above shows that the economy has experienced a dwindling performance during the period of the financial liberalisation in Nigeria. 


\section{Literature Review:}

\section{Savings and Investment under Financial Liberalisation}

According to McKinnon (1973) and Shaw (1973) high interest rate that evolve in economy after liberalisation will reduces inflation rate, induces savings to grow and this in turn induces higher rate of return and consequently increases investment and leads to economic growth. Previous studies attempt to investigate the link between savings and investment and many more on financial liberalisation dwelled on whether it has positive effect on savings and investment. Attanasio, Picci, and Scorcu (2000) for example study the long run and short run correlation between savings, investment and growth for 123 countries over a period of 1961to 1994. The research concluded that there exist positive and significant relationship between lagged savings and investment rates. Secondly, it also found a negative causality between investment and economic growth. And lastly, positive causality running from growth to investment. Since the study is cross country, it is important to have a country specific study to critically examine the validity of this conclusion and particularly re-examine the assertion of negative causality between investment and growth which contradicts most of the results obtained in the literature like that of (Barro, 1991) and (Barro \& Lee, 1993).

Change in reforms may account for this negative or mixed results obtained in the previous studies. Abiad, Oomes, and Ueda (2008) noted this, and argued that basically to two main reasons might account for the mixed or ambiguous quantity effect of financial liberalisation reform for instance. Firstly, increase in rate of return due to improve in risk sharing 
and or removal of interest rate may depend on whether income or substitution effect prevails. If income effect prevails, quantity effect will be negative. But if substitution effect holds, the quantity effect will be positive. Secondly, even if financial liberalisation provides better insurance against risk, this may possibly lower the incentive to save for future (Devereux \& Smith, 1994). Therefore, financial liberalisation can improve the functioning of financial market without necessarily increasing the volume of savings and investment.

De Melo and Tybout (1986) examined the effect of financial liberalisation on savings and investment using time series data for Uruguay spanning from 1962 to 1983 . The study built some simple econometric models and tested whether private savings response to changes in interest rate, and whether also the low private investment in the Uruguayan economy may be attributable to the reform. With regards to credit allocation, the study concluded there has been observed significant improvement in the allocation of credit. However, this cannot be certainly linked to the reform due macroeconomic imbalance that rocked the economy immediately after the reform. With respect to savings, other exogenous variables like foreign capital inflows play significant role in influencing its behaviour. And at the same time, savings response to interest rate positively only during the pre-reform period but not after liberalisation reform.

Otiwu, Okere, and Uzowuru (2018) examined the determinant of private savings in Nigeria from 1981 to 2015 using vector error correction to investigate on the relationship between savings and investment by incorporating some financial market indicators such financial deepening and financial inclusion measures. Their findings show that interest rate 
is not significant determinant of private savings in Nigeria. What influences domestic private savings in Nigeria are per capita income and financial inclusion. Although the study found that interest rate is insignificant but positively correlated with savings, it argued that high interest rate will encourage more domestic savings in the economy and also recommend that policy makers should intensify effort in designing policies that can enhance growth in income and investment to stimulate private savings.

Mamoon and Nicholas, (2017) analysed the validity of the financial liberalisation proposition by identifying two key channels through which the reform affects the economy, increasing the volume saving by the influence of higher returns and through allocative efficiency. The document a total failure of the reform in both the two channels with respect to Pakistan economy. Although, the result appears not supportive of the reform, a further study is needed to address the shortcomings by this study. In their study, they treated all the variables exogenous, while problems of endogeneity and simultaneity may likely occur as opined by De Melo and Tybout (1986), as such model that captures this potential problem is required to be able to validate their findings.

Ueda (2000) argued that competition among banks can make firms to internalised external effect in investment and this can have positive effect of volume of savings. Closely looking at the financial reform in Nigeria, it has led to the expansion of the banks' credit to private sector. For instance, in 1986 credit to private sector was targeted at 12.80 percent by the monetary authorities. However, by the end of the year, the actual credit to private sector stood at 29.43 percent. Most of the 
expansion happened within the last two quarters of 1986 partly as a response to announcement effect of naira devaluation by the government, and partly due to the impact of the reform (Ayogu et al., 1998). The effect of the announcement prompted individuals and firms to rush and borrow in the domestic banks in order to settle their loans, especially foreign currency denominated loans. This led to the upwards oscillation in the credit trend and continues to grow upwards throughout the reform period until it reached its highest peak of 91.20 percent in actual sense as against the targeted rate of 30 percent in the year 2007 .

There was also a belief that, the impact created by the reform in boosting credit in the economy was the inducement of borrowing on the part of firms that wanted to conclude their projects before the commencement of the devaluation as well as those that were trying to fund their working capital requirements. Credit expansion continued through the 1990s. The expansion of credit in the 1990s can be linked to the directives of the government for banks to grant loans to general public without much restrictions for the purchase of share in other to accomplish the privatization exercise (Ayogu et al., 1998).

On the other hand, the expansion of credit to its highest level in 2007 was as a result of excess liquidity both from oil revenue and capital flows that hit the banking sectors from 2004 to 2007. This, couple with the inability of the fiscal authorities to find a better way of mopping up of the excess inflows from the sales of crude oil that accrued to the country. Owing to this, the amount held in Nigerian deposit banks increased tremendously. As excess liquidity continues to grow, alongside with banking consolidation, these speeds up the volume of credit in the economy. It is important to note that before 2000 , foreign 
direct investment and debt were the dominant in terms of foreign inflows to Nigeria (Okpanachi, 2012) but after lifting the ban regarding dividend and profit repatriation, the stock market begun to experience rapid growth that attract some global speculators into the Nigerian economy as noted by (Okpanachi, 2012).

Therefore, as from 2008 the total credit to private sector started declining which mark the beginning of the country's financial crises. For example, credit to private sector dropped to 59.49 percent in 2008 from its highest peak of 91.20 percent in 2007, then to 26.80 percent and -3.81 percent in 2009 and 2010 respectively (CBN Statistical Bulletin, 2017). The overheating of the Nigeria's financial system that led to the boost in 2009 was as a result of the over lending by the banks to investors mainly for speculative purposes (Sanusi, 2010) in the middle of 2000s. Obamuyi (2009) also made similar observation when investigating the impact of financial liberalisation on the development of private sectors in Nigeria. The study utilized both descriptive and quantitative techniques and the results of the finding show that credits to private sector have no positive and significant impact on the economic growth. This means that either the credits are channel to unproductive activities, or they were used for trade and commerce which Sanusi, (2010) said to be used for speculative trading in the stock that led to the economic turmoil in 2009.

It is a clear evidence that fast credit expansion might heighten instability and enhances the risk of financial crises as it has happened in many parts of the world. Griffith-Jones (2016) has observed this trend and argued that just like the Global Financial Crises of 2007/2008, the Nigerian financial crises of 2009 was associated with rapid credit 
expansion which was brought about by assets price bubbles, triggering instability and subsequently collapse of the financial system. Despite the fact that the banking system had become stronger with the Central Bank recapitalization exercise, it did not stop the economy from plummeting into financial crises. This is because the growth of the credit was associated with unproductive activities, credit misallocation, coupled with regulatory failures (Sanusi, 2010). The collapse led to an increase in the volume of non-performing loans which rise from 9.5 percent in 2007 to about 30 percent in 2009. In other to restore confidence and stability in the economy, the central bank had to rescue about nine banks that were about to collapse at the cost of four billion US dollars (Ostry et al., 2011)

In summary, according to McKinnon (1973) and Shaw (1973), financial liberalisation affects the economy through two channels; savings and allocative efficiency. Firstly, through savings channel, financial development affects the real economy by enhancing the volume of savings in the economy. This is because savings levels are sensitive to real interest rates, nominal interest rate and inflation reduces the amount of national income allocated to capital formation. This implies that in a financially repressed economy, the financial market after liberalisation will stimulate higher returns on savings instrument like the savings account via high interest rate. This will help to attract savings from the informal sector into the formal sector.

The second channel is through allocative efficiency. As the financial institutions generate more savings, they will be able to extend the accumulated savings into productive investment thereby increasing the overall economic performance (Mamoon and Nicholas, 2017). One 
medium through which the financial institutions can foster allocative efficiency is by extending credit to private sector which is considered to be more efficient than to public sector. Because of high efficiency in the private sector, they were expected to utilized the funds efficiently by investing in a more profitable project. Hence, the country's productive efficiency improves while economy is set at a positive growth track.

\section{Model Specification}

This section presents some models based on the work of De Melo and Tybout (1986) to account for the relationship between domestic savings and some financial liberalisation indicators. However, the specification here differs slightly from their own work as this study account for the role of stock market development in the liberalisation processes. The model is specified as follows;

$$
\begin{gathered}
s_{t}=\beta_{0}+\beta_{1} y_{t}+\beta_{2} r_{t}+\beta_{3} f_{t}+\beta_{3} s_{t-1}+\beta_{3} l_{t}+\beta_{4} k_{t} \\
+\varepsilon \ldots \ldots \ldots \ldots \ldots \ldots \ldots \ldots \ldots \ldots \ldots
\end{gathered}
$$

Equation (1) above states that domestic savings, $s_{t}$, depends on: real income, $y_{t}$, real deposit rate $r_{t}$, foreign saving $f_{t}$, lagged savings $s_{t-1}$, stock market liquidity $l_{t}$ and stock market capitalisation $k_{t}$.

Real income growth is included in the model to account for the deviation from permanent income as suggested by the standard theory. Changes in income influences both savings and consumption as emphasised by (Keynes, 1936). According to him, rise in income often accompanied by a rise in savings. Therefore, its coefficient is expected to be positive. Lagged saving is included in the model to capture the adjustment process which is assumed to be spread over multiple periods and its coefficient is assumed to be positive. Foreign savings is included 
in the model to capture the degree of substitutability between foreign savings and private savings. If foreign savings crowd out private savings, the resultant effect on the coefficient would be positive. considering individuals may consume more at any given rate of capital accumulation. Interest rate is included because traditionally, savings behaviour is sensitive to real returns on savings, if the effect of the reforms on savings hold true, the coefficient is expected to be positive and significant. Stock Market indicators are included to account the extent to which investors switched their portfolios quickly and cheaply between alternative options. They are also important indicators of how capital is efficiently allocated in the economy. There are empirical studies that considered the links between stock market and savings notable here are; (Ewah, Esang, \& Bassey, 2009) and (Pushpakumara \& Anthony, 2009). Ewah et al. (2009) observed the link with respect to Nigeria while Pushpakumara and Anthony (2009) observed with respect to Sri Lanka. The two studies both show that there exist a positive association between stock market development with savings.

De Melo and Tybout (1986) noted that, estimating equation (1) may results to some specification issues. Firstly. According to financial liberalisation hypothesis, interest rate response positively to private savings not total domestic savings. Therefore, results in equation (1) should be handle with caution. Secondly, foreign savings may not be necessarily determined exogenously. This is because as the country's capital account is opened following liberalisation, economic agents may opt to optimised their present and future consumption of both domestic and foreign goods at any given interest rate, exchange rate, income and expectation. Lastly, financial liberalisation in Nigeria follows some policy reversal. Therefore, it is important to account for some 
institutional changes that took place within the period of study such as interest rate control reversal.

To address the issues raised above, equation (1) is re-specified and estimated with private savings instead of total savings and a dummy variable is included as well to capture the structural break. Thus, equation (2) is specifies as follows;

$$
\begin{gathered}
p s_{t}=\beta_{0}+\beta_{1} y_{t}+\beta_{2} r_{t}+\beta_{3} f_{t}+\beta_{4} p s_{t-1}+\beta_{5} l_{t}+\beta_{6} k_{t}+\beta_{7} D_{t} \\
+\varepsilon_{t} \ldots \ldots \ldots \ldots \ldots \ldots(2)
\end{gathered}
$$

Furthermore, in order to test whether factors associated with financial liberalisation explained efficient allocation of investment in the Nigerian economy, another model was developed. It is important to recall that when the economy is financially repressed, firms' investment is depended largely on their accumulated incomes. However, in a liberalised economy, real price of capital and the expected output demand play significant role in this aspect. Hence a model in the form of equation (3) is necessary that relates firms' investment with income as follows;

$$
\begin{array}{r}
i_{t}=\beta_{0}+\beta_{1} y_{t}+\beta_{2} r_{t}+\beta_{3} e_{t}+\beta_{4} m_{t}+\beta_{5} l_{t}+\beta_{6} k_{t}+\beta_{7} D_{t} \\
+\beta_{8} y_{t-1}+\beta_{9} m_{t-1}+\beta_{10} i_{t-1}+\varepsilon_{t} \ldots \ldots \ldots \ldots \ldots \ldots
\end{array}
$$

Equation (3) states that investment $i_{t}$ depends on its lagged value $i_{t-1}$, income $y_{t}$ and its lagged value $y_{t-1}$, interest rate $r_{t}$, exchange rate $e_{t}$, real money growth $m_{t}$ and its lagged value $m_{t-1}$, market capitalisation $k_{t}$, stock market liquidity $l_{t}$ and a dummy $\mathrm{D}$ that captures that effect of institutional changes, if any, to see if there is any significant break within sample period. 
The complication in estimating these three equations is the possibility of inconsistent parameter estimation arising due to endogenous regressors. In these models, interest rate and income or both may be endogenous with respect to savings in equation (1), as well as with exchange rate or both in equation (2) and (3). Therefore, instrumental variables may provide a better way of obtaining consistent parameter estimates in this case. The data used in the regression were sourced online from World Bank Development Indicators, Central Bank of Nigeria Annual Statistical Bulletins, 2017.

\section{Results and Discussion}

Table 2 shows the regression result from the standard investment function derived from equation (1). Four different models were estimated and reported in the four different columns with savings as dependent variable in each case. The first model was estimated with the assumption of no endogeneity among the regressors. while equation 
Table 2: Standard Savings Function

\begin{tabular}{|c|c|c|c|c|}
\hline Variables & Model 1 & Model 2 & Model 3 & Model 4 \\
\hline & $\begin{array}{l}\text { Domestic } \\
\text { Savings }\end{array}$ & $\begin{array}{l}\text { Domestic } \\
\text { Savings }\end{array}$ & $\begin{array}{l}\text { Domestic } \\
\text { Savings }\end{array}$ & $\begin{array}{l}\text { Domestic } \\
\text { Savings }\end{array}$ \\
\hline Y & $\begin{array}{l}-0.185 * * \\
(0.0713)\end{array}$ & $\begin{array}{l}-0.383 * * \\
(0.123)\end{array}$ & $\begin{array}{l}-0.187 * \\
(-2.51)\end{array}$ & $\begin{array}{l}-0.568 * * \\
(-2.80)\end{array}$ \\
\hline $\mathrm{R}$ & $\begin{array}{l}0.156^{*} \\
(0.0792)\end{array}$ & $\begin{array}{l}0.160 * * \\
(0.0873)\end{array}$ & $\begin{array}{l}0.304 * * \\
(2.92)\end{array}$ & $\begin{array}{l}0.0361 \\
(0.21)\end{array}$ \\
\hline $\mathrm{F}$ & $\begin{array}{l}2.351 * * \\
(0.418)\end{array}$ & $\begin{array}{l}2.606 * * \\
(0.476)\end{array}$ & $\begin{array}{l}2.658 * * \\
(5.82)\end{array}$ & $\begin{array}{l}2.581 * * \\
(4.25)\end{array}$ \\
\hline $\mathrm{S}_{\mathrm{t}-1}$ & $\begin{array}{l}0.348^{* *} \\
(0.0988)\end{array}$ & $\begin{array}{l}0.359 * * \\
(0.109)\end{array}$ & $\begin{array}{l}0.312 * * \\
(2.98)\end{array}$ & $\begin{array}{l}0.402 * * \\
(2.84)\end{array}$ \\
\hline $\mathrm{K}$ & $\begin{array}{l}-0.000335^{* *} \\
(0.0000905)\end{array}$ & $\begin{array}{l}-0.000415^{* *} \\
(0.000107)\end{array}$ & $\begin{array}{l}-0.000340 * * \\
(-3.59)\end{array}$ & $\begin{array}{l}-0.000487 * * \\
(-3.42)\end{array}$ \\
\hline $\mathrm{L}$ & $\begin{array}{l}0.115^{* *} \\
(0.0380)\end{array}$ & $\begin{array}{l}0.151 * * \\
(0.0452)\end{array}$ & $\begin{array}{l}0.134 * * \\
(3.30)\end{array}$ & $\begin{array}{l}0.168 * * \\
(2.94)\end{array}$ \\
\hline const. & $\begin{array}{l}2.814 * * \\
(1.058)\end{array}$ & $\begin{array}{l}3.277 * * \\
(1.187)\end{array}$ & $\begin{array}{l}1.473 \\
(1.18)\end{array}$ & $\begin{array}{l}4.879 * \\
(2.32)\end{array}$ \\
\hline $\begin{array}{l}\text { Endogenous } \\
\text { variables }\end{array}$ & None & $\mathrm{Y}$ & $\mathrm{R}$ & $\mathrm{y}, \mathrm{r}$ \\
\hline $\begin{array}{l}\text { Durbin p-value } \\
\text { Hausman p- } \\
\text { value }\end{array}$ & ---- & $\begin{array}{l}0.0211 \\
0.0361\end{array}$ & $\begin{array}{l}0.0145 \\
0.0255\end{array}$ & $\begin{array}{l}0.0082 \\
0.0152\end{array}$ \\
\hline $\begin{array}{l}\mathrm{R}^{2} \\
\text { Rmse }\end{array}$ & $\begin{array}{l}0.814 \\
1.626\end{array}$ & $\begin{array}{l}0.774 \\
1.792\end{array}$ & $\begin{array}{l}0.808 \\
1.649\end{array}$ & $\begin{array}{l}0.748 \\
1.890\end{array}$ \\
\hline
\end{tabular}

Standard errors in parentheses, $* \mathrm{p}<0.05, * * \mathrm{p}<0.01$ 
From the regression results, interest rate appeared to be significant and positive in all the cases except in column 4 . In addition, the correlation between the interest rate and savings tends to be moderate ranging from 15 percent to 30 percent. This provide a significant support for the claim that financial liberalisation stimulate savings controlling for other factors. If interest rate raised by 1 percent for instance, savings will grow by 15 to 30 percent. Furthermore, foreign savings also shows strong positive correlation with savings. In line with a priory expectation that financial liberalisation would cause foreign savings to crowd-out domestic savings. The coefficient in all the regressions is greater than one, meaning that foreign savings crowd out domestic savings in more than one-to-one fashion. Market capitalisation also appeared to crowd out domestic savings, albeit weak correlation. This is because of the assumption that stocks and bonds provide savings alternative to household and investors. As such, the available savings in bank will decline with a slight improvement in stock market due to the financial reforms.

The coefficient of income or the marginal propensity to save in all the regressions is negative. This means that income growth negatively correlated with domestic savings. The implication of this result is that ether there is an increasing return-to scale in the economy, or the agents faces financial constraints, or there is increasing uncertainty in the economy. Either of these can cause savings to fall with respect to increase in income. For example, if there is increasing expectation about future uncertainty in the economy (increase in inflation, currency deterioration etc), agents might borrow much they can to avoid being worst off in the future. Similarly, if there is increasing return to scale, 
firms might find it beneficial to increase the level of their debt in anticipation of future return.

As stated above, the specification of model (1) slightly contradicted what has been posit by the financial liberalisation tenet, it is important re-estimate the model with private savings and observe the results. Table 3 reported the regression results based on the five different hypotheses about the issue of endogeneity of the parameters estimated. In the first column it assumed endogeneity. In the column 2-5, it tested the presence of endogeneity using income

growth, interest rate, foreign savings and both income and interest rate. The discussion is as follows. 
Table 3: Regression based on Private Savings Function

\begin{tabular}{|c|c|c|c|c|c|}
\hline Variables & Model 1 & Model 2 & Model 3 & Model 4 & Model 5 \\
\hline & $\begin{array}{l}\text { Private } \\
\text { Savings }\end{array}$ & $\begin{array}{l}\text { Private } \\
\text { Savings }\end{array}$ & $\begin{array}{l}\text { Private } \\
\text { Savings }\end{array}$ & $\begin{array}{l}\text { Private } \\
\text { Savings }\end{array}$ & $\begin{array}{l}\text { Private } \\
\text { Savings }\end{array}$ \\
\hline $\mathrm{Y}$ & $\begin{array}{l}-0.0739 * \\
(0.0341)\end{array}$ & $\begin{array}{l}-0.449 * \\
(0.183)\end{array}$ & $\begin{array}{l}-0.0829 * \\
(0.0365)\end{array}$ & $\begin{array}{l}-0.449 * \\
(0.190)\end{array}$ & $\begin{array}{l}-0.103 * * \\
(0.0381)\end{array}$ \\
\hline $\mathrm{R}$ & $\begin{array}{l}-0.0359 \\
(0.0426)\end{array}$ & $\begin{array}{l}0.0404 \\
(0.114)\end{array}$ & $\begin{array}{l}0.103 \\
(0.0814)\end{array}$ & $\begin{array}{l}0.0395 \\
(0.140)\end{array}$ & $\begin{array}{l}0.0465 \\
(0.0530)\end{array}$ \\
\hline $\mathrm{F}$ & $\begin{array}{l}0.722 * \\
(0.339)\end{array}$ & $\begin{array}{l}1.468^{* *} \\
(0.512)\end{array}$ & $\begin{array}{l}0.991 * * \\
(0.350)\end{array}$ & $\begin{array}{l}1.466^{* * *} \\
(0.497)\end{array}$ & $\begin{array}{l}1.313^{* *} \\
(0.376)\end{array}$ \\
\hline$(\mathrm{ps})_{\mathrm{t}-1}$ & $\begin{array}{l}0.829 * * \\
(0.106)\end{array}$ & $\begin{array}{l}0.679^{* *} \\
(0.192)\end{array}$ & $\begin{array}{l}0.761 * * \\
(0.113)\end{array}$ & $\begin{array}{l}0.679 * * \\
(0.190)\end{array}$ & $\begin{array}{l}0.701 * * * \\
(0.119)\end{array}$ \\
\hline $\mathrm{K}$ & $\begin{array}{l}- \\
0.000178 \\
* \\
(0.00007 \\
44)\end{array}$ & $\begin{array}{l}- \\
0.00036 \\
* * \\
(0.00012 \\
0)\end{array}$ & $\begin{array}{l}- \\
0.000198 \\
* * \\
(0.00007 \\
69)\end{array}$ & $\begin{array}{l}- \\
0.00036 \\
* * \\
(0.00012 \\
1)\end{array}$ & $\begin{array}{l}- \\
0.000281 \\
* * \\
(0.00008 \\
56)\end{array}$ \\
\hline $\mathrm{L}$ & $\begin{array}{l}0.0836 * * \\
(0.0285)\end{array}$ & $\begin{array}{l}0.159^{* * *} \\
(0.0610)\end{array}$ & $\begin{array}{l}0.0999 * * \\
(0.0321)\end{array}$ & $\begin{array}{l}0.158^{* * *} \\
(0.0607)\end{array}$ & $\begin{array}{l}0.0875 * \\
(0.0348)\end{array}$ \\
\hline $\mathrm{D}$ & $\begin{array}{l}-7.827 * * \\
(1.242)\end{array}$ & $\begin{array}{l}-4.551 \\
(2.439)\end{array}$ & $\begin{array}{l}-6.867 * * \\
(1.314)\end{array}$ & $\begin{array}{l}-4.555 \\
(2.394)\end{array}$ & $\begin{array}{l}-6.324 * * \\
(1.457)\end{array}$ \\
\hline const. & $\begin{array}{l}0.859 \\
(0.611)\end{array}$ & $\begin{array}{l}2.320 * \\
(1.081)\end{array}$ & $\begin{array}{l}0.136 \\
(0.854)\end{array}$ & $\begin{array}{l}2.328 \\
(1.404)\end{array}$ & $\begin{array}{l}1.052 \\
(0.573)\end{array}$ \\
\hline $\begin{array}{l}\text { Endogeno } \\
\text { us } \\
\text { variables }\end{array}$ & None & $\mathrm{y}$ & $\mathrm{R}$ & $\mathrm{y}, \mathrm{r}$ & $\mathrm{f}$ \\
\hline $\begin{array}{l}\mathrm{R}^{2} \\
\text { Rmse }\end{array}$ & $\begin{array}{l}0.825 \\
1.135\end{array}$ & $\begin{array}{l}0.567 \\
1.786\end{array}$ & $\begin{array}{l}0.809 \\
1.185\end{array}$ & $\begin{array}{l}0.566 \\
1.787\end{array}$ & $\begin{array}{l}0.809 \\
1.184\end{array}$ \\
\hline
\end{tabular}

Standard errors in parentheses, ${ }^{*} \mathrm{p}<0.05, * * \mathrm{p}<0.01$ 
This alternative specification produced poor results if compared with the estimation in Table 2 both in terms of individual and overall level of significant. The R-square declined, measures of financial liberalisation especially interest rate is not significant in all the five variants of the estimations. Meaning that it plays no role in determining private savings as maintained by the proponents of liberalisation reform. This result is similar to the result found by Otiwu et al. (2018). The moderate correlation found in the first model with total savings disappeared with regressing the variables on private domestic savings. The dummy variable indicates that, after controlling for other factors, there is a downward shift in the savings function after liberalisation. With respect to foreign savings, however, there is a declined in the degree of substitutability with private domestic savings looking at the magnitude of the coefficients. Meaning that there is a fall in crowding out of foreign savings with domestic private savings. Private savings has strong and significant positive correlation with its lagged value. This points out to the importance of the long run effect of other determinant of private savings - past accumulated private savings plays important role in determining current domestic private savings. The result is consistence to the findings of (Loayza, Schmidt-Hebbel, \& Servén, 2000). The coefficient of income remained significant although, with weak negative correlation. This result contrasted the findings of (Loayza et al., 2000). Stock market indicators too do not show any positive and significant performance with respect to the private savings and the results almost remained unchanged if compared with the first regression.

This subsection will test the hypothesis about the impact of financial liberalisation on allocation efficiency. One of the targets of liberalising the financial sector is to hasten the pace of capital formation or 
investment in nut shell. Not only accelerating the growth in investment, but to efficiently allocate the investment into most profitable project, with high positive net present value. To do so, there is need to estimate equation (3) to see whether factors associated with financial liberalisation responsible for fluctuations in the investment as documented in section one. Table 4 present the regression result. 
Table 4: Regression of the Investment Function

\begin{tabular}{|c|c|c|c|c|}
\hline Variables & Model 1 & Model 2 & Model 3 & Model 4 \\
\hline & Investment & Investment & Investment & Investment \\
\hline $\mathrm{Y}$ & $\begin{array}{l}0.0413 \\
(0.120)\end{array}$ & $\begin{array}{l}0.387 \\
(0.247)\end{array}$ & $\begin{array}{l}-0.0150 \\
(0.0674)\end{array}$ & $\begin{array}{l}-0.873 \\
(0.618)\end{array}$ \\
\hline Ly & $\begin{array}{l}-0.119 \\
(0.0924)\end{array}$ & $\begin{array}{l}-0.202 \\
(0.129)\end{array}$ & $\begin{array}{l}-0.223 \\
(0.190)\end{array}$ & $\begin{array}{l}-0.0676 \\
(0.286)\end{array}$ \\
\hline $\mathrm{M}$ & $\begin{array}{l}0.0280 \\
(0.0351)\end{array}$ & $\begin{array}{l}0.0289 \\
(0.0325)\end{array}$ & $\begin{array}{l}-0.0132 \\
(0.0350)\end{array}$ & $\begin{array}{l}-0.00814 \\
(0.0705)\end{array}$ \\
\hline $\mathrm{Lm}$ & $\begin{array}{l}0.0569 \\
(0.0377)\end{array}$ & $\begin{array}{l}0.0670 \\
(0.0422)\end{array}$ & $\begin{array}{l}0.0177 \\
(0.0429)\end{array}$ & $\begin{array}{l}-0.00106 \\
(0.0644)\end{array}$ \\
\hline $\mathrm{E}$ & $\begin{array}{l}0.0165 \\
(0.0267)\end{array}$ & $\begin{array}{l}0.0362 \\
(0.0280)\end{array}$ & $\begin{array}{l}0.159 * * \\
(0.0548)\end{array}$ & $\begin{array}{l}0.129 * \\
(0.0538)\end{array}$ \\
\hline Le & $\begin{array}{l}-0.0283 \\
(0.0307)\end{array}$ & $\begin{array}{l}-0.0569 \\
(0.0346)\end{array}$ & $\begin{array}{l}-0.140 * * * \\
(0.0749)\end{array}$ & $\begin{array}{l}-0.0907 \\
(0.0800)\end{array}$ \\
\hline $\mathrm{R}$ & $\begin{array}{l}-0.366^{*} \\
(0.186)\end{array}$ & $\begin{array}{l}-0.368 * \\
(0.182)\end{array}$ & $\begin{array}{l}0.106 \\
(0.167)\end{array}$ & $\begin{array}{l}0.00751 \\
(0.489)\end{array}$ \\
\hline $\mathrm{D}$ & $\begin{array}{l}-5.509 * \\
(2.182)\end{array}$ & $\begin{array}{l}-5.416^{*} \\
(2.434)\end{array}$ & $\begin{array}{l}-4.949 * * * \\
(2.552)\end{array}$ & $\begin{array}{l}-4.924 \\
(2.513)\end{array}$ \\
\hline $\mathrm{Li}$ & $\begin{array}{l}0.985 * * \\
(0.228)\end{array}$ & $\begin{array}{l}0.881 * * \\
(0.263)\end{array}$ & $\begin{array}{l}1.054 * * \\
(0.255)\end{array}$ & $\begin{array}{l}1.319 * * \\
(0.376)\end{array}$ \\
\hline $\mathrm{K}$ & $\begin{array}{l}0.000186 \\
(0.000237)\end{array}$ & $\begin{array}{l}0.000484 \\
(0.000355)\end{array}$ & $\begin{array}{l}-0.000153 \\
(0.000261)\end{array}$ & $\begin{array}{l}-0.000865 \\
(0.000716)\end{array}$ \\
\hline $\mathrm{L}$ & $\begin{array}{l}-0.00916 \\
(0.0989)\end{array}$ & $\begin{array}{l}-0.0753 \\
(0.127)\end{array}$ & $\begin{array}{l}0.281 * * \\
(0.0851)\end{array}$ & $\begin{array}{l}0.441 \\
(0.263)\end{array}$ \\
\hline Constant & $\begin{array}{l}3.486 \\
(2.306)\end{array}$ & $\begin{array}{l}4.054 \\
(3.009)\end{array}$ & $\begin{array}{l}-0.868 \\
(2.034)\end{array}$ & $\begin{array}{l}-1.050 \\
(5.983)\end{array}$ \\
\hline $\begin{array}{l}\text { Endogenous } \\
\text { variables }\end{array}$ & $\mathrm{R}$ & $\mathrm{Y}$ & $\mathrm{e}$ & $\mathrm{y}, \mathrm{r}, \mathrm{e}$ \\
\hline
\end{tabular}




\begin{tabular}{|l|l|l|l|l|}
\hline $\begin{array}{l}\text { Durbin } \\
\text { Hausman }\end{array}$ & 0.0282 & 0.0725 & 0.0269 & 0.0070 \\
R-square & 0.9655 & 0.1076 & 0.0642 & 0.0000 \\
\hline
\end{tabular}

Standard errors in parentheses $* p<0.05, * * p<0.01, * * * p<0.1$

Regression result in table 4, shows that real money growth does not have any impact on investment. In the mainstream economics view, growth in money supply has a positive and significant causal relationship with output growth (Sturgill, 2014). Sturgill further argued that it was as a result of higher economic freedom that makes money growth a positive and significant determinant of output growth. However, the result in this study shows no evidence that growth in money supply plays a significant effect on investment growth in Nigeria. Furthermore, interest rate which is key variable in the context of liberalisation plays no role on investment. Where it appears to be significant like in column 1 and 2 , it has a negative impact on investment. Meaning that a raised in interest rate can result to a decline in investment. It shows that firms are sensitive to increase in the price of capital This contradicts the financial liberalisation hypothesis and the Modigliani and Miller (1958) theory that in a perfectly competitive market cost of capital is irrelevant. Although, income and its lagged value appeared insignificant, as such there is no substantial evidence to show that firms switched to personal or business income for their investment. This perhaps, could be as a result that savings with respect to income change is negative as it has seen in table 2 and 3. However, lagged investment is found to have strong and positive correlation with investment. Meaning that firms rely much on their past performances to forecast for future investment. Notwithstanding, there is no substantial evidence that accumulated profit in the past investment are important 
determinant of current investment. Hence, there is a mild evidence that the standard accelerator mechanism holds valid for part of the sample model. This result is similar to what De Melo and Tybout (1986) found in their study. Similarly, Eberly, Rebelo, and Vincent (2012) concluded that lagged investment is best predictor of investment than Tobin's Q.

Exchange rate on the other hand is statistically significant and positively related with investment. This positive association means that appreciation in exchange rate may lead to an increase in investment. The idea behind it is that as exchange rate appreciated, the cost of imported inputs falls and this increases the profit of firms creating incentive to invest more. Raising interest rate will reduces investment, perhaps due to predominantly increase in macroeconomic uncertainty especially with respect to inflation and volatility in the exchange rate. If this assumption holds true, it then means that firms are risk averse in the economy, decreasing investment with a rising interest rate in order to avoid future risk. The finding is similar to De Melo and Tybout (1986) but contradicted (Canbaloglu \& Gurgun, 2017) in a cross-country study that shows real exchange rate has negative and insignificant impact on investment. The conclusion of their study suggests that, domestic investors in such countries are risk-neutral and insensitive to adjustment cost related to exchange rate volatility as well as investment irreversibility.

With respect to capital market variable, aside market liquidity in column 3 , in all the regression options it shows that the market is insignificant in allocation of investment to productive sectors in the economy. This result is supportive by many empirical studies that highlighted that firms in developing countries do not use capital market to raise funds. Finally, 
the dummy variable shows that the models shift downward. This means that there are exogenous factors responsible for the fluctuations in investment.

\section{Conclusion}

Previous research on financial liberalisation in developing countries identified number of channels through which financial market reforms affect allocation of resources. Firstly, increase in interest rate may lead to growth in savings. Secondly, relaxation of financial constraints may lead to growth in investment. The empirical relevance of these two effects to Nigerian economy was tested in this study and the major findings are presented here below.

In equation (1), total domestic savings was used and the results shows that financial liberalisation enhances savings growth in Nigeria and some key variables assumed to determine savings following the literature were included in the models. Virtually all the determinants are statistically significant and in line with the expected signs. However, based on the assumption that financial liberalisation affects private savings not total domestic savings, the model was re-estimated using private savings as dependent variable instead of domestic savings. The second regression significantly differs with the first even though, similar in some aspect. In the second estimation, interest rate, which is the key element, plays no significant role in determining savings in Nigeria. While financial depth measured by stock market capitalisation reduces both domestic and private savings. Both domestic savings and private savings falls with a rise in income. But fall is larger in domestic income than in private savings 
Concerning investment model, the result shows that accelerator theory exerts significant impact in explaining the investment behaviour of the Nigerian economy throughout the sample period. The standard accelerator theory posits that investment depends on expectation. And from all the four different investment models that were estimated, the results show that the lagged investment is significant and strongly correlated with investment. The conclusion is that expectation is more relevant in explaining investment behaviour in Nigeria within the study period than savings constraints. In addition, the downward structural shift, suggested that the financial liberalisation reform does not provide concrete evidence about improvement in investment in the Nigerian economy. Interest rate which is key in the reform exercise appeared negative, and insignificant in some cases same with money growth and measures of stock market performances.

The findings of this study show that Nigeria is not savings constrained, but rather credit constrained. Since interest rate plays no significant role in determining savings in Nigeria, and a unit increase in the interest rate may also lead to significant decline in domestic investment. This can be clearly seen in Table 1 where investment in fixed capital formation has been continually declining while savings remains relatively stable. The study therefore recommends that policies that favours liberalising the interest rate in the country is of little importance. What matters much is addressing other macroeconomic issues that impede the allocation of credit to productive projects such as interest regulation, income and consumption policies as well as reducing macroeconomic uncertainties. The study also recommends that future research should focus on addressing the micro channels through which financial liberalisation affects savings and investment in Nigeria. 


\section{References}

Abiad, A., Oomes, N., \& Ueda, K. (2008). The quality effect: Does financial liberalization improve the allocation of capital? Journal of Development Economics, 87(2), 270-282.

Attanasio, O. P., Picci, L., \& Scorcu, A. E. (2000). Saving, growth, and investment: a macroeconomic analysis using a panel of countries. Review of Economics and Statistics, 82(2), 182-211.

Ayogu, M., Emenuga, C., \& Soludo, C. (1998). Country case studies: Nigeria Financial reform in developing countries: IDRC, Ottawa, ON, CA.

Barro, R. J. (1991). Economic growth in a cross section of countries. The Quarterly Journal of Economics, 106(2), 407-443.

Barro, R. J., \& Lee, J.-W. (1993). Losers and winners in economic growth. The World Bank Economic Review, 7(suppl_1), 267-298.

Canbaloglu, B., \& Gurgun, G. (2017). The Impact of Exchange Rate Uncertainty on Domestic Investment: Panel Evidence from Emerging Markets and Developing Economies Financial Management from an Emerging Market Perspective: IntechOpen.

De Melo, J., \& Tybout, J. (1986). The effects of financial liberalization on savings and investment in Uruguay. Economic Development and Cultural Change, 34(3), 561-587.

Devereux, M. B., \& Smith, G. W. (1994). International risk sharing and economic growth. International economic review, 535-550. 
Eberly, J., Rebelo, S., \& Vincent, N. (2012). What explains the laggedinvestment effect? Journal of monetary economics, 59(4), 370-380.

Ewah, S. O., Esang, A. E., \& Bassey, J. U. (2009). Appraisal of capital market efficiency on economic growth in Nigeria. International Journal of Business and Management, 4(12), 219-225.

Griffith-Jones, S. (2016). Achieving financial stability and growth in Africa Financial Liberalisation (pp. 133-175): Springer.

Kar, D., \& LeBlanc, B. Illicit Financial Flows from Developing Countries: 20022011, year $=2013$, institution $=$ Global Financial Integrity. Retrieved from

Keynes, J. M. (1936). The General Theory of Employment, Interest and Money (London, 1936). KeynesThe General Theory of Employment, Interest and Money1936.

Loayza, N., Schmidt-Hebbel, K., \& Servén, L. (2000). What drives private saving across the world? Review of Economics and Statistics, 82(2), 165-181.

McKinnon, R. I. (1973). Money and capital in economic development: Brookings Institution Press.

Modigliani, F., \& Miller, M. H. (1958). The cost of capital, corporation finance and the theory of investment. The American, 1, 3.

Newman, C., Page, J., Rand, J., Shimeles, A., Söderbom, M., \& Tarp, F. (2016). Manufacturing transformation: comparative studies of industrial development in Africa and emerging Asia: Oxford University Press.

Nwaobi, G. C. (2003). Savings Mobilization Role of Nigerian Commercial Banks: An Analytical Policy Study. Retrieved from 
Obamuyi, T. M. (2009). Government financial liberalization policy and development of private sector in Nigeria: Issues and challenges. Accessible online at www. africa-platform. org/download/file/fid/274.

Okpanachi, U. M. (2012). An assessment of monetary policy response to capital inflows in Nigeria. CBN Journal of Applied Statistics, 3(2), 75-98.

Ostry, J. D., Ghosh, A. R., Habermeier, K. F., Laeven, L., d Chamon, M., Qureshi, M. S., \& Kokenyne, A. (2011). Managing Capital Inflows; What Tools to Use? Retrieved from

Otiwu, K., Okere, P. A., \& Uzowuru, L. (2018). Determinants of Private Domestic Savings in Nigeria (1981-2015). International Journal for Innovation Education and Research, 6(2), 21-40.

Pushpakumara, W., \& Anthony, C. (2009). Determinants of stock market development in Sri Lanka.

Sanusi, L. (2010). The Nigerian Banking Industry: what went wrong and the way forward. Delivered at Annual Convocation Ceremony of Bayero University, Kano held on, 3(1), 2010.

Shaw, E. S. (1973). Financial deepening in economic development.

Ueda, K. (2000). Increasing Returns, Long-Run Growth and Financial Intermediation. Paper presented at the Econometric Society World Congress 2000 Contributed Papers.

World Bank, World Development Indicators (2017). Retrieved from https://data.worldbank.org/ 